\title{
A survey of public knowledge and attitude towards tissue, cell donation and transplantation in the Republic of Moldova
}

\author{
${ }^{* 1,2}$ Tatiana Timbalari, ${ }^{3}$ Oleg Lozan, ${ }^{1}$ Igor Codreanu, ${ }^{2}$ Viorel Nacu \\ ${ }^{1}$ Transplantology Department, Transplant Agency, Chisinau, the Republic of Moldova \\ ${ }^{2}$ Laboratory of Tissue Engineering and Cells Culture, ${ }^{3}$ School of Public Health Management \\ Nicolae Testemitanu State University of Medicine and Pharmacy, Chisinau, the Republic of Moldova \\ Authors' ORCID iDs, academic degrees and contributions are available at the end of the article \\ *Corresponding author: tatiana.timbalari@gmail.com \\ Manuscript received July 27, 2020; revised manuscript April 12, 2021; published online April 28, 2021
}

\begin{abstract}
Background: Numerous studies focusing on public attitude towards organ donation have been performed at the international level, but very few highlight public attitude towards tissue and cell donation and transplantation.

Material and methods: We conducted a survey among a representative sample of the general adult population $(\mathrm{N}=427)$. The questionnaire was developed on the basis of previous study and included reuse of some items from the earlier survey to facilitate historical comparison. The analysis of the data was carried out using SPSS, 2011 and focused on descriptive statistics.

Results: The vast majority of our respondents (81.0\%) agreed with the tissue and cell donation and only every 10th respondent did not accept this. The fewer respondents $(68.1 \%)$ would agree to have tissues and cells transplanted from other people compared to those who were willing to donate tissues and cells (81.0\%). Finally, most of the respondents (85.0\%) expressed interest in receiving more information, and were very similar to those in receiving more information on organ donation and transplantation $(88.0 \%)$

Conclusions: The study revealed the respondents' positive attitude towards tissue and cell donation and transplantation and demonstrated a remarkable growth in the public positive attitude towards donation. Furthermore, as the vast majority of our respondents wanted to receive more information on these issues, it seems to be a clear opportunity to develop educational and promotional strategies to improve awareness and enhance donation rates in our country.

Key words: donation, transplantation, tissue, cell, public attitude, public knowledge.
\end{abstract}

Cite this article

Timbalari T, Lozan O, Codreanu I, Nacu V. A survey of public knowledge and attitude towards tissue, cell donation and transplantation in the Republic of Moldova. Mold Med J. 2021;64(2):42-48. https://doi.org/10.52418/moldovan-med-j.64-2.21.08.

\section{Introduction}

Discussions on how best to increase tissue and cell stocks often focus on the issue of donor motivation: in particular, how people can best be encouraged to donate different types of human material [1-3]. It is essential to refer to the Convention on Human Rights and Biomedicine, which, in Article 21, clearly states that "The human body and its parts shall not, as such, give rise to financial gain" [4].

A well-known fact is that all donation and transplantation programmes are dependent upon the willingness and voluntary commitment to donate organs, tissues and cells from donors to continue their activity [5-9]. So, it is important that public confidence is maintained by standards of good practice $[1,10]$.

According to the WHO successful donation and transplantation programs should include at least appropriate public awareness strategies, which promote not only organ donation but also tissue and cell donation $[2,10]$. One of these programs is in Spain, named as the Spanish Model of Donation and Transplantation, and today it is recommend- ed as the gold standard worldwide, prioritizing the development of logistics starting with the identification of the donor until the removal of organs, tissues and cells $[11,12]$.

Numerous studies focusing on public attitude towards organ donation have been performed at the international level, but very few surveys highlight public attitude towards tissue and cell donation and transplantation [13-16].

The purpose of the survey in the Republic of Moldova among a representative sample of the general adult population was to assess the knowledge and attitude towards tissue and cell donation and transplantation to identify the factors that may increase the willingness to donate.

\section{Material and methods}

The survey was performed to determine the public knowledge and attitude towards tissue and cell donation and transplantation during the five consecutive working days by the initially trained staff. A total of 450 participants from adult population were randomly selected to complete anonymously the specially developed questionnaire, consisting 
of 15 questions. A total of 427 valid questionnaires were obtained. The questionnaire was grouped into compartments according to the information collected. The respondents were asked to carefully choose the answer option considered the closest from their personal point of view. In order to facilitate processing of the results, as well as to avoid the indecision of the respondents, we preferred to eliminate the intermediate or neutral values from the assessment scale. The study protocol was approved by the Ethics Committee of Nicolae Testemitanu State University of Medicine and Pharmacy, Chisinau (No 2, 27.10.2016).

The self-administered questionnaire was voluntary completed by 246 (57.6\%) women and 181 (42.4\%) men. Depending on age, the respondents were distributed as follows: 156 (36.5\%) persons were aged within 18 - 34 years, $145(34.0 \%)$ persons - within 35 - 54 years, $126(29.5 \%)$ persons - within 55 - 82 years. The average age of the respondents was $42.38 \pm 0.7$ years. The average age was statistically significantly higher in men $-44.75 \pm 1.1$ years, compared with women $-40.64 \pm 1.0$ years $(\mathrm{p}<0.01)$.

Statistical processing of the material was based on the special files elaborated where the primary data were coded - the results of the questionnaires. The analysis of the data was computerized using the software "Statistical Package for the Social Science” version 20.0 for Windows (SPSS, Inc., Chicago, IL, 2011). A multivariate analysis using logistic regression was carried out to find the social determinants of supporting donation and transplantation and information available to them. The results are based on descriptive and inferential statistics.

\section{Results}

The general adult population. The study population included statistically significant more women under the age of 35 and more men aged within $35-54$ years $(\mathrm{p}<0.05)$.

Depending on the educational level, 131 (30.7\%) respondents had university education, 114 (26.7\%) respondents had high school or college education, 103 (24.1\%) respondents had general or vocational education and 79 (18.5\%) respondents had incomplete secondary education (fig. 1).

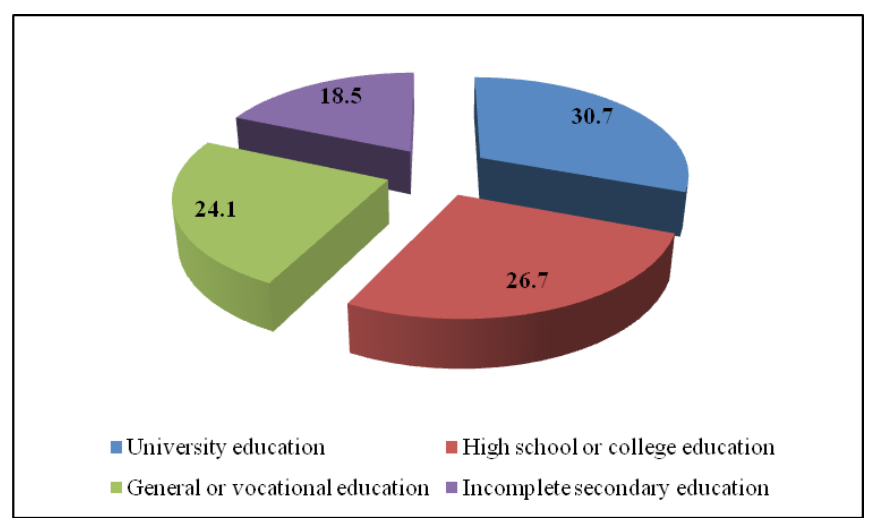

Fig. 1. Distribution of the respondents by their educational level (\%)
In accordance with the occupational level, our respondents were distributed as follows: $163(38.2 \%)$ persons were registered as employees, $30(7.0 \%)$ persons were employed as private entrepreneurs, $80(18.7 \%)$ persons were temporarily unemployed and 154 (36.1\%) persons did not work (tab. 1).

Table 1. Distribution of the respondents by gender and occupation

\begin{tabular}{|c|c|c|c|c|c|c|c|c|}
\hline \multirow{2}{*}{ Gender } & \multicolumn{7}{|c|}{ Occupation } \\
\cline { 2 - 10 } & \multicolumn{2}{|c|}{ Employee } & \multicolumn{2}{|c|}{$\begin{array}{c}\text { Unem- } \\
\text { ployed }\end{array}$} & \multicolumn{2}{c|}{$\begin{array}{c}\text { Temporarily } \\
\text { unemployed }\end{array}$} & $\begin{array}{c}\text { Private } \\
\text { entrepre- } \\
\text { neur }\end{array}$ \\
\cline { 2 - 10 } & abs. & $\%$ & abs. & $\%$ & abs. & $\%$ & abs. & $\%$ \\
\hline Female & 97 & 39.4 & 88 & 35.8 & 46 & 18.7 & 15 & 6.1 \\
\hline Male & 66 & 36.5 & 66 & 36.5 & 34 & 18.8 & 15 & 8.3 \\
\hline Total & 163 & 38.2 & 154 & 36.1 & 80 & 18.7 & 30 & 7.0 \\
\hline
\end{tabular}

More than half of the respondents surveyed - 237 (55.5\%) - came from urban areas and 190 (44.5\%) respondents came from rural areas.

The survey showed that the respondents from the general adult population were presented by urban women aged 18-34, with university education and were registered as employees.

Attitude towards tissues and cells donation and transplantation. The respondents' attitude towards tissue and cell donation and transplantation has been analysed. We found that the vast majority of our respondents -346 $(81.0 \%)$ agreed with tissue and cell donation and only 40 (9.4\%) respondents did not accept it, 36 (8.4\%) respondents did not know and 5 (1.2\%) respondents did not respond (fig. 2). Statistically significant differences in those opinions depending on gender were not found ( $p>0.05)$.

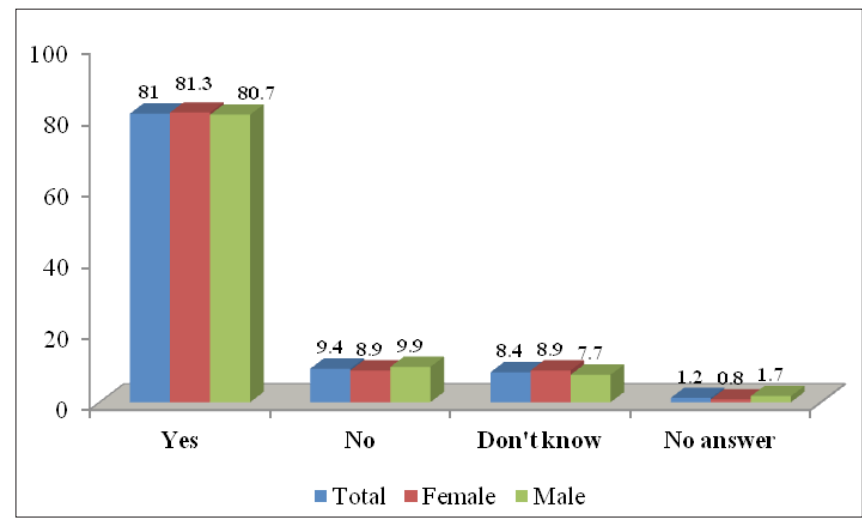

Fig. 2. Willingness to donate own tissues and cells (\%)

We correlated this with the age and residential environment of our respondents and found that the statistically significant differences in those opinions were also not revealed ( $>0.05$ ) (fig. 3, 4). 


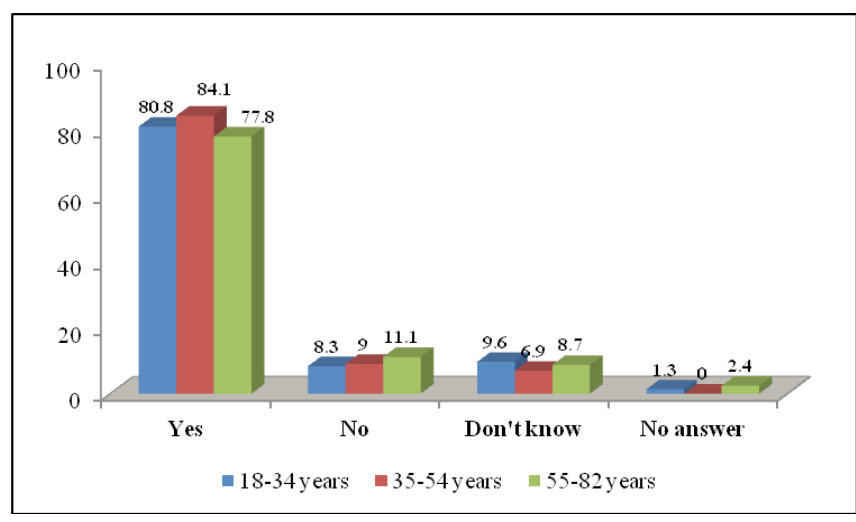

Fig. 3. Willingness to donate own tissues and cells by age (\%)

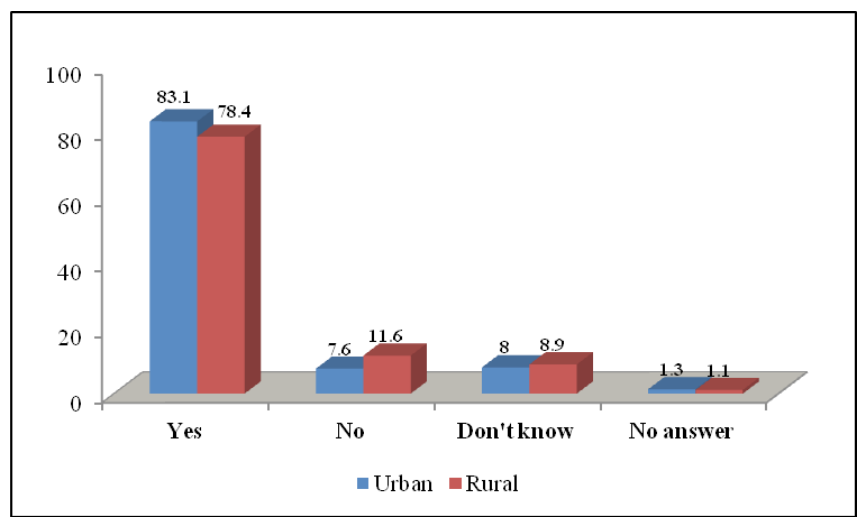

Fig. 4. Willingness to donate own tissues and cells by residential environment (\%)

The correlation with the educational level of our respondents found that the respondents with university education agreed with tissue and cell donation, statistically more frequently compared to the respondents with incomplete secondary education $(87.0 \%$ and $67.1 \%$, respectively; $\mathrm{p}<0.001$ ), and the respondents with high school or college education agreed with donation, statistically more frequently compared to the respondents with incomplete secondary education $(85.1 \%$ and $67.1 \%$, respectively; $\mathrm{p}<0.01)$. At the same time, the respondents with incomplete secondary education, statistically more frequently compared to the respondents with university education did not agree with donation $(12.7 \%$ and $6.1 \%$, respectively; $\mathrm{p}<0.05)$. From those undecided, the respondents with incomplete secondary education, statistically more frequently compared to the respondents with university education $(17.7 \%$ and $6.9 \%$, respectively; $\mathrm{p}<0.05$ ), with high school or college education $(17.7 \%$ and $5.3 \%$, respectively; $p<0.01)$ and with general or vocational education $(17.7 \%$ and $6.8 \%$, respectively; $\mathrm{p}<0.05)$ answered that they did not know (fig. 5).

The estimation of frequency of this opinion depending on occupational level also found statistically significant differences: the private entrepreneurs agreed with tissue and cell donation statistically more frequently compared to the employees ( $93.3 \%$ and $82.2 \%$, respectively; $\mathrm{p}<0.05)$, the respondents who were temporarily unemployed $(93.3 \%$ and $71.3 \%$, respectively; $\mathrm{p}<0.01$ ) and the unemployed respondents $(93.3 \%$ and $82.5 \%$, respectively; $p<0.05$ ) (fig. 6 ).

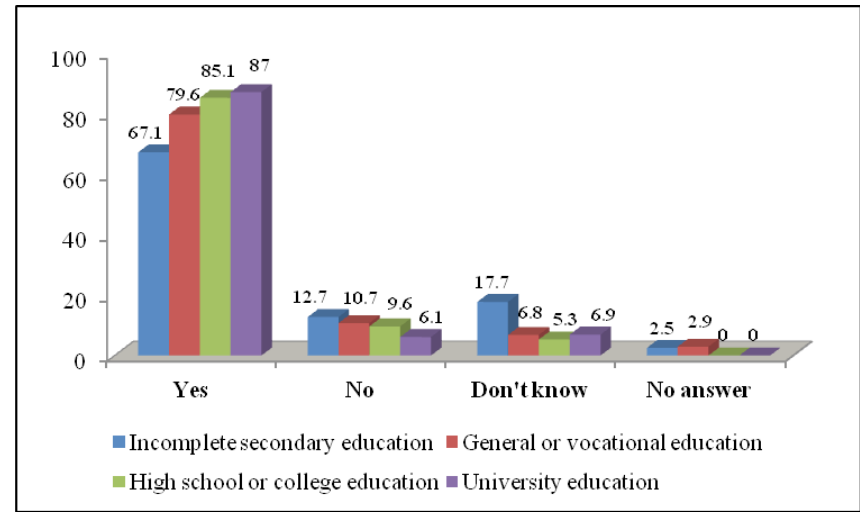

Fig. 5. Willingness to donate own tissues and cells by educational level (\%)

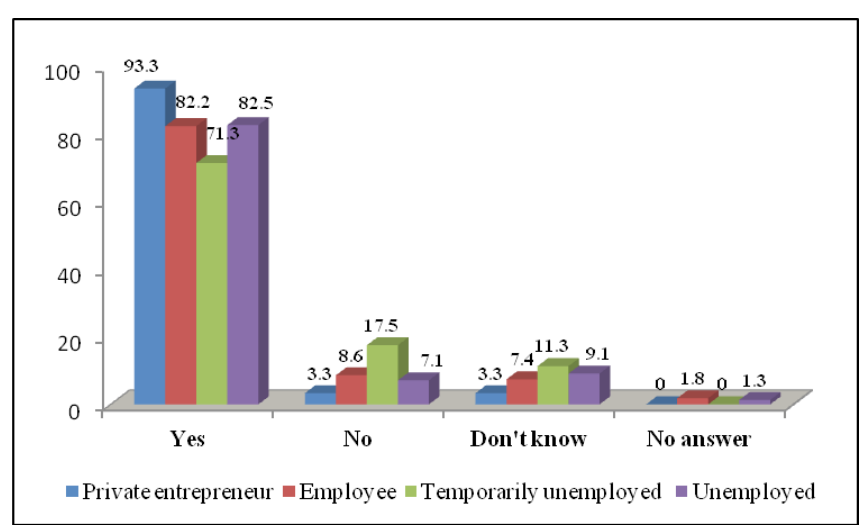

Fig. 6. Willingness to donate own tissues and cells by occupation (\%)

Meanwhile, more temporarily unemployed respondents did not agree with donation than private entrepreneurs $(17.5 \%$ and $3.3 \%$, respectively; $\mathrm{p}<0.01)$ and the unemployed respondents $(17.5 \%$ and $7.1 \%$, respectively; $\mathrm{p}<0.05)$. From those undecided, more temporarily unemployed respondents did not agree with donation than private entrepreneurs $(11.3 \%$ and $3.3 \%$, respectively; $\mathrm{p}<0.01)$ and employees $(11.3 \%$ and $7.4 \%$, respectively $\mathrm{p}<0.01)$.

The survey data analysis showed that in case if the life of a family member could be saved by tissue or cell transplant, $349(81.7 \%)$ respondents would agree to donate these tissues or cells during life, provided that their lives would not be endangered, $40(9.4 \%)$ respondents would not agree to donate, 33 (7.7\%) respondents did not know and $5(1.2 \%)$ respondents did not respond. Depending on gender, the results shown above were similar ( $p>0.05$ ) (fig. 7).

Our study revealed that the respondents' opinion that a close relative can become a deceased donor was generally positive: 109 (25.5\%) respondents had a very good opinion, $170(39.8 \%)$ respondents had a good opinion, $24(5.6 \%)$ respondents had a neutral opinion, 24 (5.6\%) respondents had a bad opinion, $11(2.6 \%)$ respondents had a very bad opinion, 72 (16.9\%) respondents did not know and 17 (4.0\%) respondents did not answer. These opinions were statistically similar by gender $(\mathrm{p}>0.05)$. So, the significant majority of the respondents (65.3\%) had a very good and good opinion in case a close relative became a deceased donor. 


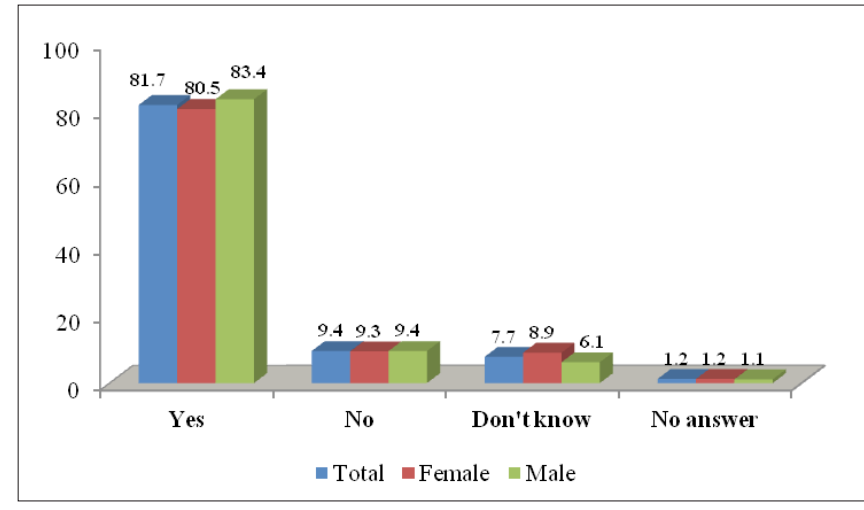

Fig. 7. Willingness to donate own tissues and cells to a family member (\%)

As a result of the research it was established that the significant majority of our respondents 299 (70.0\%) would accept post-mortem sampling of their healthy tissues to be transplanted to others, $69(16.2 \%)$ respondents would not accept post-mortem sampling, 51 (11.9\%) respondents did not know and 8 (1.9\%) respondents did not respond (fig. $8)$. Differences in the frequencies of these results by gender were not statistically significant $(\mathrm{p}>0.05)$.

Our study demonstrated that if necessary, the significant majority of the respondents 291 (68.1\%) would agree to receive tissues and cells from other people, 61 (14.3\%) respondents would not accept this, 69 (16.2\%) respondents did not know and 6 (1.4\%) respondents did not answer (fig. 9). These results were similar by gender $(\mathrm{p}>0.05)$.

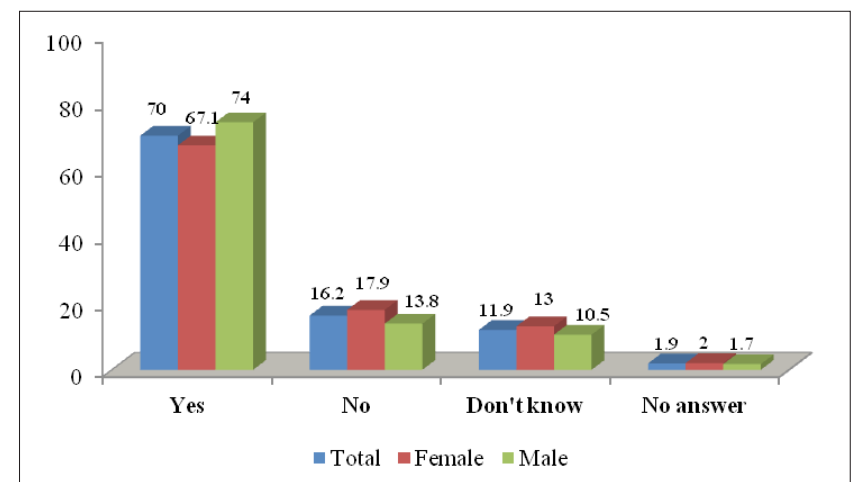

Fig. 8. Willingness to donate own tissues and cells upon death (\%)

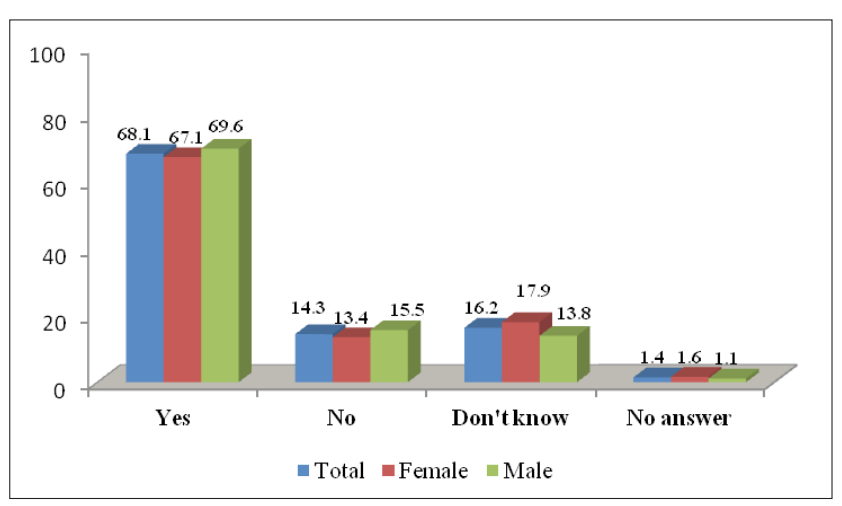

Fig. 9. Willingness to receive tissues and cells from other people (\%)
Knowledge in the field of tissue and cell donation and transplantation. The evaluation of the quality and quantity of information on tissue and cell donation and transplantation found that $157(36.8 \%)$ respondents considered they had sufficient information, 183 (42.9\%) respondents considered this information insufficient, 71 (16.6\%) respondents did not know, 16 (3.7\%) respondents did not answer (fig. 10).

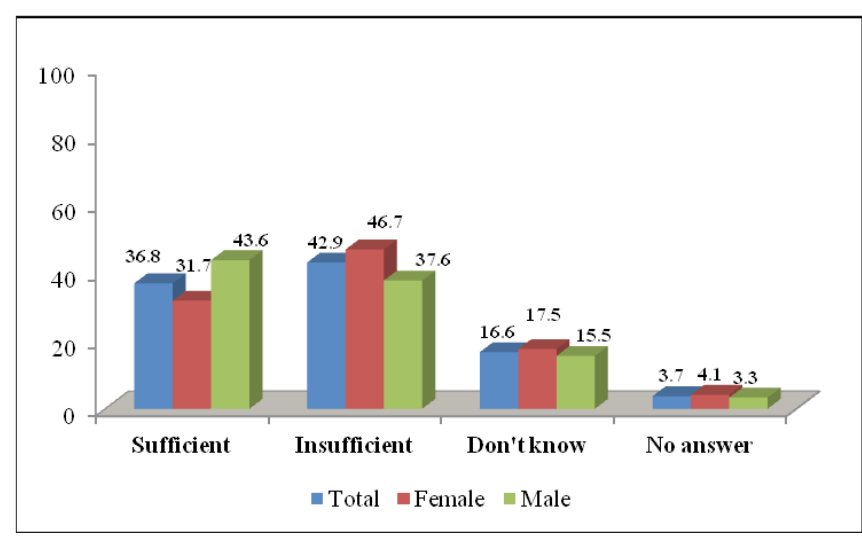

Fig. 10. Volume of information on tissue and cell donation and transplantation (\%)

Significant differences in the frequency of our respondents' opinion were found depending on the educational level and the residential environment.

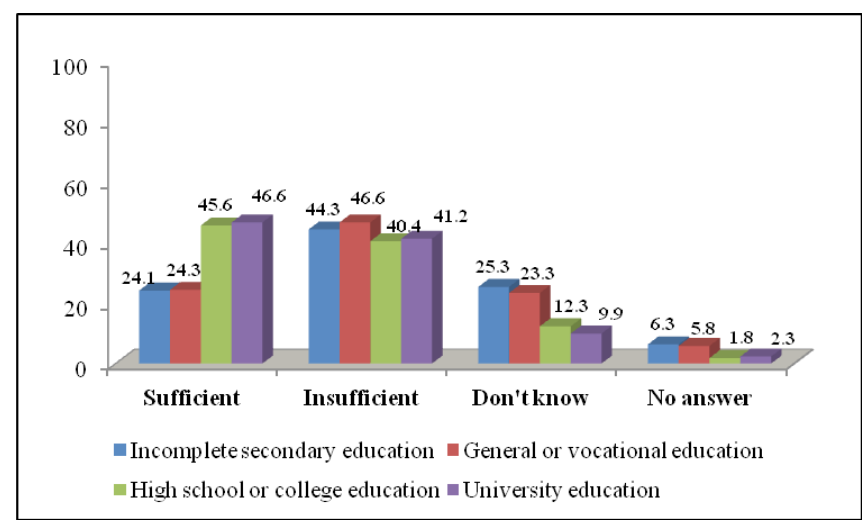

Fig. 11. Volume of information on tissue and cell donation and transplantation by educational level (\%)

Our respondents with high school or college education considered this information to be sufficient, statistically more frequently compared to the respondents with incomplete secondary education $(45.6 \%$ and $24.1 \%$, respectively; $\mathrm{p}<0.01)$ and with general or vocational education $(45.6 \%$ and $24.3 \%$, respectively; $\mathrm{p}<0.001$ ) (fig. 11 ). The respondents with university education also considered this information to be sufficient, statistically more frequently compared to the respondents with incomplete secondary education ( $46.6 \%$ and $24.1 \%$, respectively; $\mathrm{p}<0.001$ ) and with general or vocational education $(46.6 \%$ and $24.3 \%$, respectively; $\mathrm{p}<0.001)$.

Depending on the residential environment, 102 (43.0\%) 
urban respondents considered they had sufficient information, 98 (41.3\%) urban respondents considered this information insufficient, 30 (12.7\%) did not know and 7 (3.0\%) did not answer. Respectively, 55 (28.9\%) rural respondents considered they had sufficient information, 85 (44.8\%) rural respondents considered this information insufficient, 41 (21.6\%) did not know and 9 (4.7\%) did not answer (fig. 12).

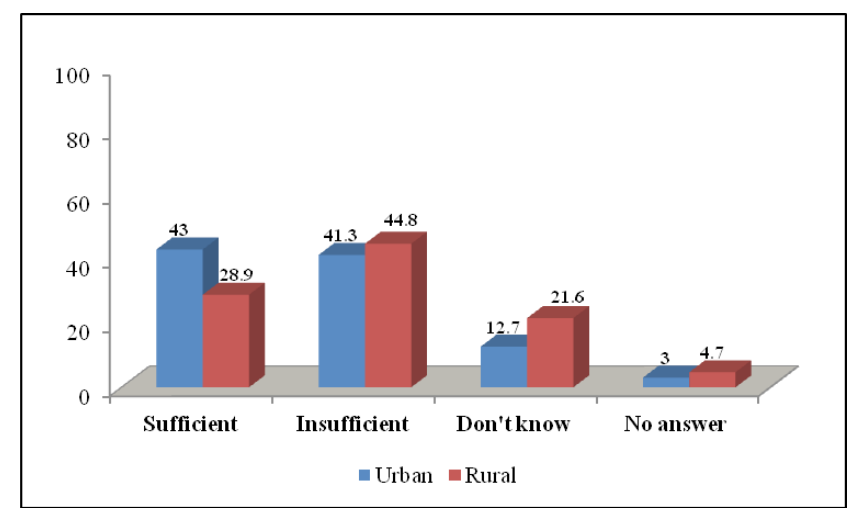

Fig. 12. Volume of information on tissue and cell donation and transplantation by residential environment (\%)

Our respondents from urban areas mentioned that this information is sufficient, statistically more frequently compared to the respondents from rural areas $(43.0 \%$ and $28.9 \%$, respectively; $\mathrm{p}<0.01$ ), but the respondents from rural areas mentioned that they did not know, statistically more frequently compared to the respondents from urban areas $(21.6 \%$ and $12.7 \%$, respectively; $\mathrm{p}<0.05)$.

It is important to mention that the vast majority of our respondents - $363(85.0 \%)$ wanted to receive more information on tissue and cell donation and transplantation. For such information claimed $87.2 \%$ of respondents up to 34 years old, $89.0 \%$ of respondents aged $35-54$ years and $77.8 \%$ - aged 55 years or above $(\mathrm{p}<0.05)$ (fig. 13).

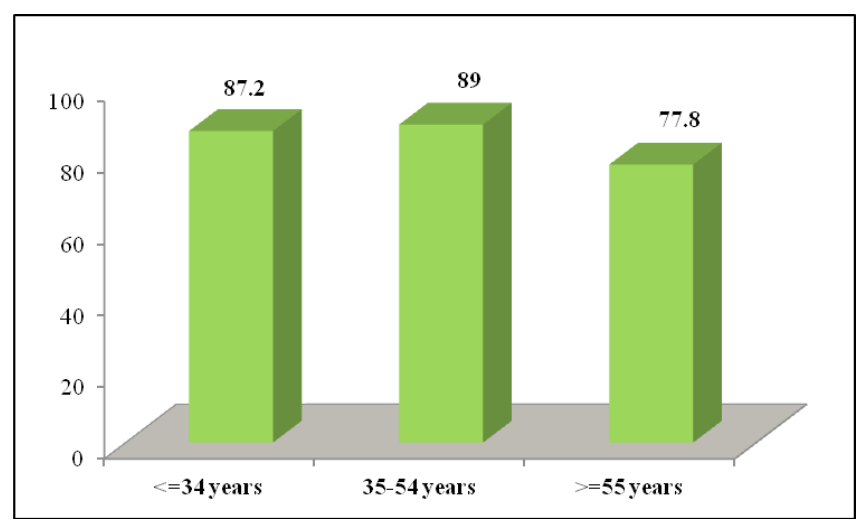

Fig. 13. Interested in having more information on tissue and cell donation and transplantation by age (\%)

The correlation with the educational level exposed the fact that the respondents with high school or college education requested the information on tissue and cell donation and transplantation, statistically more frequently compared to the respondents with incomplete secondary education (92.1\% and $81.0 \%$, respectively; $\mathrm{p}<0.05)$ and with general or vocational education $(92.1 \%$ and $75.7 \%$, respectively; $\mathrm{p}<0.01$ ), but the respondents with university education requested such information, statistically more frequently compared to the respondents with general or vocational education ( $88.5 \%$ and $75.7 \%$, respectively; $\mathrm{p}<0.05$ (fig. 14).

Therefore, the opinion of our respondents on the quality and quantity of information on tissue and cell donation and transplantation was similar in terms of age, but depended on gender, educational level and residential environment. Request for more information depended on age and educational level.

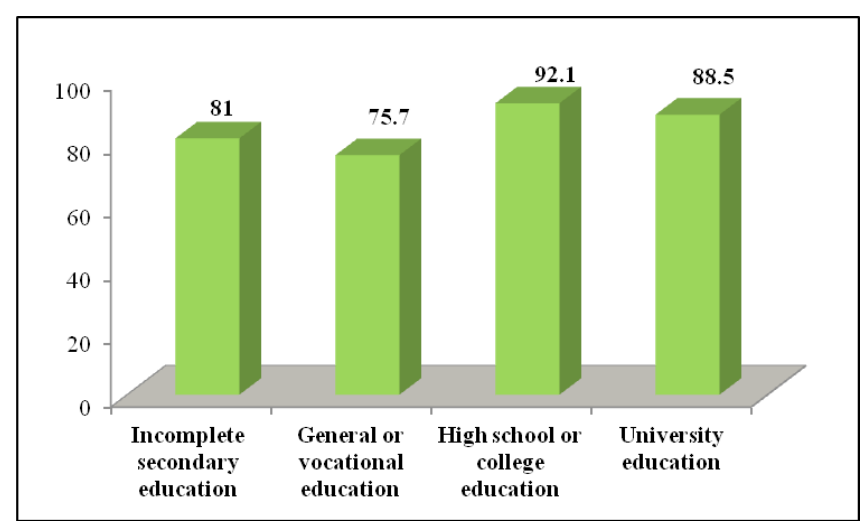

Fig. 14. Interested in having more information on tissue and cell donation and transplantation by educational level (\%)

The evaluation of the respondents' opinion on the need to obtain permission from relatives to procure tissues from the deceased person found that about $2 / 5-170$ (39.8\%) of respondents believed that such permission should always be obtained, $104(24.4 \%)$ respondents believed that the permission should be obtained when the deceased's opinion is unknown, 99 (23.2\%) respondents did not know, 35 (8.2\%) respondents believed that the permission should not be obtained in any case and 19 (4.4\%) respondents did not respond (fig. 15).

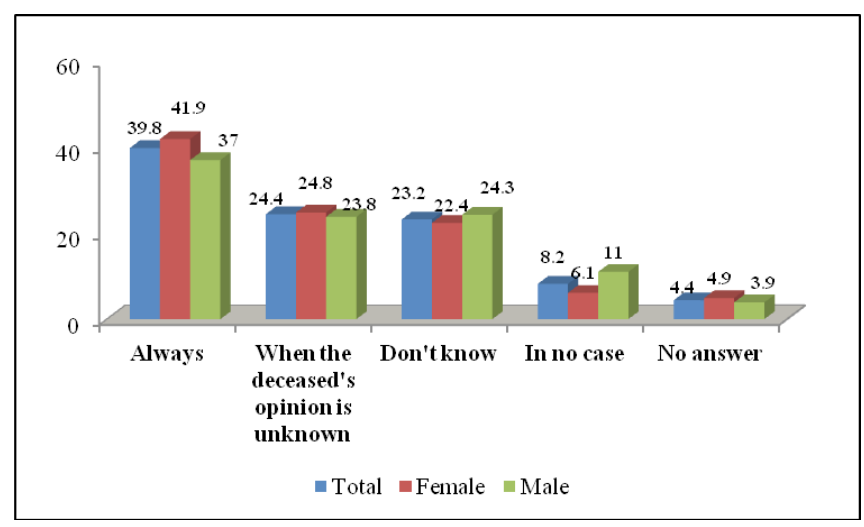

Fig. 15. Attitude towards obtaining permission from relatives for tissue procurement (\%) 


\section{Discussion}

The survey data analysis revealed that the vast majority of our respondents $(81.0 \%)$ agreed with the tissue and cell donation and only every 10 th respondent did not accept this.

Over 4 years, after conducting the first public survey on perception of donation and transplantation in $2014[17,18]$, when the agreement for donation was expressed by only $65.4 \%$ of respondents and every 5 th respondent did not accept donation, the extension of education and information actions in this field obviously sensitized the population regarding the noble gesture of donation. Our study confirmed that agreement for organ donation as well as for tissue and cell donation depended on the educational level and occupation: the higher the level of education, the higher the level of acceptance of organ, tissue and cell donation; the private entrepreneurs accepted it statistically more frequently compared to employees, temporally unemployed and unemployed respondents [18].

Therefore, in our research we established that the information actions, such as organizing campaigns to promote altruistic donation programs, the annual celebrating of the European Organ and Tissue Donation Day, ensuring citizens' access to sources of medical information, managed to highlight the importance of this medical and social resource and led to a change in the public attitude towards this field.

The results of our study are similar to international ones, which showed that while $90 \%$ of people support organ and tissue donation, only about half donate their organs and tissues [19, 20]. For example, in 2012, of all actual donors in the United States authorized through the state donor registry, $40 \%$ became organ donors, $48 \%$ ophthalmic tissue donors, and $45 \%$ donors of other tissues [19]. These numbers continued to grow and in 2018 there were $50 \%$ organ donors, $61 \%$ ophthalmic tissue donors and $56 \%$ donors of other tissues [20].

In Denmark Nordfalk F. et al. found that the vast majority of the respondents $(91.9 \%)$ are positive or very positive towards organ donation, $85.8 \%$ accept the idea of using their body after death, $85.0 \%$ are willing to donate their own organs, $82.1 \%$ are willing to donate their tissues and only $2.3 \%$ believe that too much has been done to promote organ donation [15]. Attitude towards donating an organ or tissue is very similar to the attitude towards receiving an organ $(87.4 \%)$ or a tissue $(88.6 \%)$. The fewer of respondents said that they would also be willing to donate tissues (66.2\%) and organs $(64.7 \%)$ of their relatives. Our study revealed that in our country, conversely, fewer respondents (68.1\%) would agree to have tissues and cells transplanted from other people compared to those who were willing to donate tissues and cells (81.0\%).

The results of our study showed that the vast majority of respondents (85.0\%) expressed interest in receiving more information on tissue and cell donation and transplantation, and were very similar to those in receiving more informa- tion on organ donation and transplantation (88.0\%) [18]. Moreover, the younger, statistically more frequently compared to older respondents, requested information on donation and transplantation. This fact was also confirmed by studying the attitude and knowledge towards donation and transplantation of 14-19 year old students from four urban high schools, when approximately $75 \%$ of respondents were willing to receive more information on this subject $[21,22]$.

\section{Conclusions}

1. Our study revealed the respondents' positive attitude towards tissue and cell donation and transplantation. It was found that the vast majority of our respondents generally agreed with tissue and cell donation, as well as would agree to donate their tissues and cells during their lifetime if the life of a family member could be saved by a tissue and cell transplant, provided that their life would not be endangered. We demonstrated a remarkable growth in the public positive attitude towards donation.

2. The survey data analysis showed that the agreement for tissue and cell donation depended on the educational level and occupation. Our respondents with university education and high school or college education accepted donation, statistically more frequently compared to the respondents with incomplete secondary education. The private entrepreneurs accepted donation, statistically more frequently compared to employees, temporarily unemployed and unemployed respondents. No significant differences in the frequency of this opinion according to gender, age and residential environment were found.

3. More than two-thirds of our respondents would agree to have tissues and cells transplanted from other people and would accept post-mortem self-sampling of healthy tissues to be transplanted to others.

4. Only $36.8 \%$ of our respondents considered sufficient information on tissue and cell donation and transplantation. Respondents' views on the quality and quantity of this information were similar in terms of age, but depended on gender, educational level and residential environment. So, knowledge determines attitude, which in turn influences donor motivation.

5. Most of our respondents wanted to receive more information on tissue and cell donation and transplantation. The request for information on this issue was similar depending on gender, but depended on age and educational level. This parameter was statistically more frequently met in the respondents up to 54 years old, compared to the respondents of 55 years or above, in the respondents with high school or college education and university education, compared to the respondents with incomplete secondary education and general or vocational education. It seems to be a clear opportunity to develop educational and promotional strategies to enhance donation rates. The successful training programs could significantly increase the number of donors and the transplant rate in the Republic of Moldova. 


\section{References}

1. Council of Europe, European Directorate for the Quality of Medicines \& Healthcare (EDQM). Guide to the quality and safety of tissues and cells for human application. 3rd ed. Strasbourg: EDQM; 2017. 459 p.

2. World Health Organization (WHO). Human cell and tissue transplantation [Internet]. Geneva: WHO; 2019 [cited 2019 Jul 15]. Available from: https://www.who.int/transplantation/cell_tissue/en/

3. European Committee on Organ Transplantation (CD-P-TO). Illicit and unethical activities with human tissues and cells: Addressing the need for the elaboration of an international legal instrument to protect donors and recipients. Strasbourg: EDQM; 2018. [cited 2019 Jul 18]. Available from: https://www.edqm.eu/sites/default/files/position_paper_-_illicit_and_unethical_activities_with_human_tissues_and_cells_-_november_2018.pdf

4. Council of Europe (1997) Convention for the Protection of Human Rights and Dignity of the Human Being with regard to the Application of Biology and Medicine: [the Oviedo] Convention on Human Rights and Biomedicine [Internet]. Strasbourg: CE; 1997 [cited 2019 Jul 18]. Available from: http://conventions.coe.int/Treaty/en/Treaties/Html/164. htm

5. Pokorna E, Vitko S, Ekberg H. Medical-record review of potential donor pool in the Czech Republic suggests a possible increase to more than double the number of donors. Transpl Int. 2003;16(9):633-638. doi: 10.1007/s00147-003-0564-8

6. Busic M, Lovrencic-Huzjan A. Action taken to boost donor rate in Croatia. In: Randhawa G., editor. Organ donation and transplantation - public policy and clinical perspectives. Rijeka: InTech Europe; 2012. p. $47-68$.

7. Živčić-Ćosić S, Bušić M, Župan Ž, Pelčić G, Anušić Juričić M. Jurčić Ž, et al. Development of the Croatian model of organ donation and transplantation. Croat Med J. 2013;54(1):65-70. doi: 10.3325/cmj.2013.54.65.

8. Tuppin P, Maroudy D, Gachet C, Roels L. Boosting donation rates by implementing Donor Action in France. Transplantation. 2006;82(1):633.

9. Ploeg RJ, Niesing J, Sieber-Rasch MH, Willems L, Kranenburg K, Geertsma A. Shortage of donation despite an adequate number of donors: a professional attitude? Transplantation. 2003;76(6):948-955. doi: 10.1097/01.TP.0000079317.75840.0F.

10. World Health Organization (WHO). Second Global Consultation on Regulatory Requirements for Human Cells and Tissues for Transplantation: Towards Global Harmonization through Graduated Standards. WHO Geneva, 7-9 June 2006 Report [Internet]. Geneva: WHO; 2006 [cited 2019 Jun 22]. Available from: https://www.who.int/ transplantation/2dHTTGHreport.pdf?ua=1

11. Dominguez-Gil B, Haase-Kromwijk B, Van Leiden H, et al. Current situation of donation after circulatory death in European countries. Transpl Int. 2011;24(7):676-86. doi: 10.1111/j.1432-2277.2011.01257.x.
12. Matesanz R, Domínguez-Gil B, Coll E, de la Rosa G, Marazuela R. Spanish experience as a leading country: what kind of measures were taken? Transpl Int. 2011;24(4):333-343. doi: 10.1111/j.1432-2277.2010.01204.x.

13. Gross T, Marguccio I, Martinoli S. Attitudes of hospital staff involved in organ donation to the procedure. Transpl Int. 2000;13(5):351-356. doi: $10.1007 / \mathrm{s} 001470050713$.

14. Cantarovich F, Heguilén R, Filho MA, Duro-Garcia V, Fitzgerald $\mathrm{R}$, Mayrhofer-Reinhartshuber D, et al. An international opinion poll of well-educated people regarding awareness and feelings about organ donation for transplantation. Transpl Int. 2007;20(6):512-518. doi: 10.1111/j.1432-2277.2007.00473.x.

15. Nordfalk F, Olejaz M, Jensen AMB, Skovgaard LL, Hoeyer K. From motivation to acceptability: a survey of public attitudes towards organ donation in Denmark. Transplant Res. 2016;5:5. doi: 10.1186/s13737016-0035-2.

16. Squifflet JP. Donor advocacy with special reference to Belgium. Transplant Proc. 2011;43(9):3392-3395. doi: 10.1016/j.transproceed.2011.09.051.

17. Codreanu I, Lozan O, Timbalari T. Evaluation of the transplant system in the Republic of Moldova. Management in Health [Management în sănătate]. 2014;18(4):4-10.

18. Twose J, Codreanu I, Romaniciuc G, Timbalari T, Lozan O, Valles R, et al. Attitude and knowledge about donation and transplantation in a sample of Moldovan population. In: 4th ELPAT Congress on Ethical, Legal and Psychological Aspects of Organ Transplantation; 2016 Apr 22-25; Rome, Italy.

19. Donate Life America. Donatelifeamerica.com. 2013 [Internet]. Richmond: DLA; 2013 [cited 2019 Jun 14]. Available from: https://www. donatelife.net/news/2013-national-donor-designation-report-cardreleased/

20. Donate Life America. Annual update 2019 [Internet]. Richmond: DLA; 2013 [cited 2019 Jun 22]. Available from: https://www.donatelife.net/ wp-content/uploads/2016/06/2019_AnnualUpdate.pdf

21. Codreanu I, Ciubotaru L, Timbalari T, Romanciuc G, Cuiban E, Gudima D. Children's attitude and knowledge about organ donation and transplantation. In: The 1st regional meeting of the Transplantation Society "Deceased Donation: Expanding the Donor Pool". P5; 2019 March 28-29; Istanbul, Turkey.

22. Codreanu I, Ciubotaru L, Timbalari T, Romanciuc G, Cuiban E, Gudima D. The attitude of high school students about organ donation and transplantation. In: 19th Congress of the European Society for Organ Transplantation (ESOT); 2019 Sep 15-18; Copenhagen, Denmark. p. 245.

\section{Authors' ORCID iDs and academic degrees}

Tatiana Timbalari, MD, PhD Applicant - https://orcid.org/0000-0003-1391-9107

Oleg Lozan, MD, PhD, Professor - https://orcid.org/0000-0002-1552-1496

Igor Codreanu, MD, PhD - https://orcid.org/0000-0002-3316-0516

Viorel Nacu, MD, PhD, Professor - https://orcid.org/0000-0003-2274-9912

\section{Authors' contribution}

TT designed the study, conducted the data collection, interpreted the data and drafted the first manuscript; OL examined the data; IC interpreted the data; VN revised the manuscript critically. All the authors revised and approved the final version of the manuscript.

\section{Funding}

The study was supported by Nicolae Testemitanu State University of Medicine and Pharmacy and Transplant Agency. The survey was a part of the authors' PhD programme. The authors are independent and take responsibility for the integrity of the data and accuracy of the data analysis.

Ethical approval and consent to participate. The study was approved by the Research Ethics Committee of Nicolae Testemitanu State University of Medicine and Pharmacy (protocol No 2 of 27.10.2016).

Conflict of Interests. No competing interests were disclosed. 